Acta vet. scand. 1989, 30, 483-485.

Brıef Communicatıon

\title{
Pregnancies from Bovine Oocytes Matured and Fertilized in vitro
}

Production of transgenic animals and embryo cloning are only a few examples of new biotechnological methods applied to animal embryos. All these techniques require large amounts of oocytes and early embryos. In many laboratory animals, embryos matured and fertilized in vivo are easily obtained, but with larger domestic species it requires laborious surgical procedures and the number of embryos obtained remains relatively small (Brackett et al 1982). The in vitro maturation of follicular oocytes derived from slaughterhouse ovaries and their in vitro fertilization provides large numbers of oocytes and embryos with considerably less effort. The final proof of the success in the in vitro maturation and fertilization procedure is the birth of healthy progeny. Also the normal preimplantation development of the embryos gives useful information about the efficiency of the method employed.

The purpose of this study was also to find out the developmental capacity of the in vitro-matured and -fertilized bovine oocytes with a newly adopted technique at the University of Kuopio. The experiment was carried out twice at the interval of one month.

Immature oocytes were obtained from the local abattoir. Ovaries from cows and heifers at unknown stage of the cycle were collected about $30 \mathrm{~min}$ after the slaughter and transferred to the laboratory in physiological $\mathrm{NaCl}$ at $37^{\circ} \mathrm{C}$. Follicles of $2-10 \mathrm{~mm}$ in diameter were aspirated with a $19-\mathrm{G}$ needle and a 10-ml syringe. The follicular fluid was allowed to settle in a conical centrifuge tube. Oocytes surrounded by the cumulus cell layer were collected and washed 4 times in a modified Tyrode's solution (TALP; Bavister et al. 1983). The washed cumulus-oocyte complexes were transferred into $50-\mu 1 \mathrm{ma-}$ turation drops under paraffin oil on petri dishes. The maturation medium was TALP supplemented with FSH $(2.0 \mu \mathrm{g} / \mathrm{ml}$; NIHFSH-S9), LH (10 $\mu \mathrm{g} / \mathrm{ml} ;$ NIH-LH-S17), estradiol-17 $\beta(1 \mu \mathrm{g} / \mathrm{ml}$; Sigma) and $20 \%$ Fetal Calf Serum (FSC, Boehringer Mannheim). The culture was carried out in a humidified incubator with $5 \% \mathrm{CO}_{2}$ at $+39^{\circ} \mathrm{C}$. After $24 \mathrm{~h}$ the oocytes were treated with hyaluronidase (300 IU/ml, Sigma) for $1 \mathrm{~min}$ to remove the excess of cumulus cells, washed 3 times in TALP and transferred to $50-\mu l$ fertilization drops under paraffin oil on petri dishes. The fertilization medium was another modification of TALP supplemented with $0.7 \mu \mathrm{g} / \mathrm{ml}$ heparin (Sigma).

The epididymal sperm mixture was obtained in the slaughterhouse from four different bulls. The sperm were collected from the epididymal cauda segments and stored undiluted at room temperature for $24 \mathrm{~h}$. A small aliquot of sperm suspension was diluted with TALP, centrifuged twice at $300 \mathrm{~g}$ for $10 \mathrm{~min}$ and diluted to $10-40 \times 10^{6}$ sperm $/ \mathrm{ml}$ (Parrish et al. 1986). The final volume of sperm suspension added into the fertilization drops varied from 1 to $10 \mu \mathrm{l}$ resulting in a concentration of 1 mill. spermatozoa $/ \mathrm{ml}$ in each drop.

The oocytes were removed from the fertilization drops $18-20 \mathrm{~h}$ later. In the first experiment oocytes were further kept for $24 \mathrm{~h}$ in TALP $+20 \%$ FCS in the $50-\mu$ drops under paraffin oil. The development of the 
Table 1. The developmental stages of the in vitro-matured and -fertilized bovine embryos $48 \mathrm{~h}$ after insemination.

\begin{tabular}{lccccccc}
\hline $\begin{array}{l}\text { Oocytes } \\
\text { (No) }\end{array}$ & $\begin{array}{c}\text { 1-cell } \\
(\%)\end{array}$ & $\begin{array}{c}\text { 2-cell } \\
(\%)\end{array}$ & $\begin{array}{c}\text { 3-cell } \\
(\%)\end{array}$ & $\begin{array}{c}\text { 4-cell } \\
(\%)\end{array}$ & $\begin{array}{c}5 \text {-cell } \\
(\%)\end{array}$ & $\begin{array}{c}\text { Degenerated } \\
(\%)\end{array}$ & $\begin{array}{c}\text { Cleaved } \\
(\%)\end{array}$ \\
\hline 231 & 50 & 101 & 16 & 42 & 8 & 14 & 167 \\
& $(22)$ & $(44)$ & $(7)$ & $(18)$ & $(3)$ & $(6)$ & $(72)$ \\
\hline
\end{tabular}

oocytes in the in vitro culture is shown in Table 1. The embryos were divided into three groups according to their developmental stage (Table 2). Each group of embryos was separately transferred into the oviducts of 3 synchronized intermediate hosts on day 2-3 of their reproductive cycle. In the second experiment all fertilized oocytes beyond the 2-cell stage were immediately transferred into a single cow (No 4 in Table 2).

Table 2. The recovery rates and the developmental stages of in vitro-matured and -fertilized bovine embryos after 5 days in oviducts of intermediate hosts.

\begin{tabular}{lcrr}
\hline $\begin{array}{l}\text { Inter- } \\
\text { medate } \\
\text { host }\end{array}$ & $\begin{array}{c}\text { Transferred } \\
\text { embryos } \\
\text { (No/devel stage) }\end{array}$ & $\begin{array}{c}\text { Recovery } \\
(\%)\end{array}$ & $\begin{array}{c}\text { Morula-blastocyst } \\
(\%)\end{array}$ \\
\hline 1. & $50 / 4-5$-cell & $3(6)$ & $1(33)$ \\
2. & $116 / 2-3$-cell & $63(54)$ & $4(6)$ \\
3. & $168 / 1$-cell & $103(61)$ & $21(20)$ \\
4. & $29 / 2-5$-cell & $7(24)$ & $4(57)$ \\
\hline
\end{tabular}

The transfers were done surgically into the infundibulum of the oviduct ipsilateral to the ovulation in synchronized cows under local anaesthesia. Five days after transfer the intermediate hosts were flushed non-surgically according to the normal embryo transfer protocol. The number of embryos and their developmental stages were determined. The results are shown in Table 2.

In the first experiment 4 blastocysts were transferred non-surgically into the uteri of 2 synchronized final recipients ( 2 embryos/re- cipient). Ten grade I and II morulas and blastocysts were frozen for later transfers. In the second experiment 1 morula and 3 blastocysts were transferred into 3 recipients.

Thus, a total of 8 blastocysts were transferred into 5 final recipients in these experiments. In 3 out of 5 transfers the embryos were implanted. One of these ultrasonically confirmed pregnancies aborted spontaneously at week 8 of pregnancy. By ultrasonography the first recipient heifer was found to have a twin pregnancy. She gave birth to 2 calves. The delivery of the first female calf was difficult due to a reverse position and it perished, but the other bull calf was born in good health. Another single healthy bull calf was born one month later from the second recipient.

Our results indicate that the in vitro maturation and fertilization of bovine oocytes is a feasible method for the production of large numbers of early cattle embryos for special purposes (e.g. embryo manipulation, cloning, production of transgenic animals). The methods should, however, be further developed to increase the yield of embryos and, in particular, to successfully culture the embryos in vitro to a stage where they can be transferred directly into the final recipients.

\section{Acknowledgements}

This study was financially supported by the Min1stry of Agriculture and Forestry in Finland. The technical assistance of Mrs. Paula Räty is gratefully acknowledged. 
$T$ Peura, $J$ Aalto, $V$ Rainio and

$T$ Vanha-Perttula,

Department of Anatomy and the Veterınary Research Station,

University of Kuopıo, Finland.

\section{References}

Bavister BD, Lelbfried ML, Liebermann $G \cdot$ Development of preimplantation embryos of the golden hamster in a defined culture medium. B1ol. Reprod. 1983, 28, 235-247.
Brackett BG, Bousquet D, Boice $M L$, Donawick WJ, Evans JF, Dressel MA Normal development following in vitro fertilization in the cow. B1ol. Reprod. 1982, 27, 147-158.

Parrish JJ, Susko-Parrish JL, Leibfried-Rutledge $M L$, Critser ES, Eyestone WH, First NL Bovine in vitro fertilization with frozen-thawed semen. Theriogenology 1986, 25, 591-600.

(Recelved November 10, 1989, accepted November 27, 1989).

Reprints may be requested from: T. Peura, Department of Anatomy,

University of Kuopıo, P. O. Box 6, SF-70211 Kuopı, Finland. 
